\title{
JÁRAINÉ KOMLÓDI MAGDA IS SEVENTY-YEARS OLD
}

\author{
G. FEKETE
}

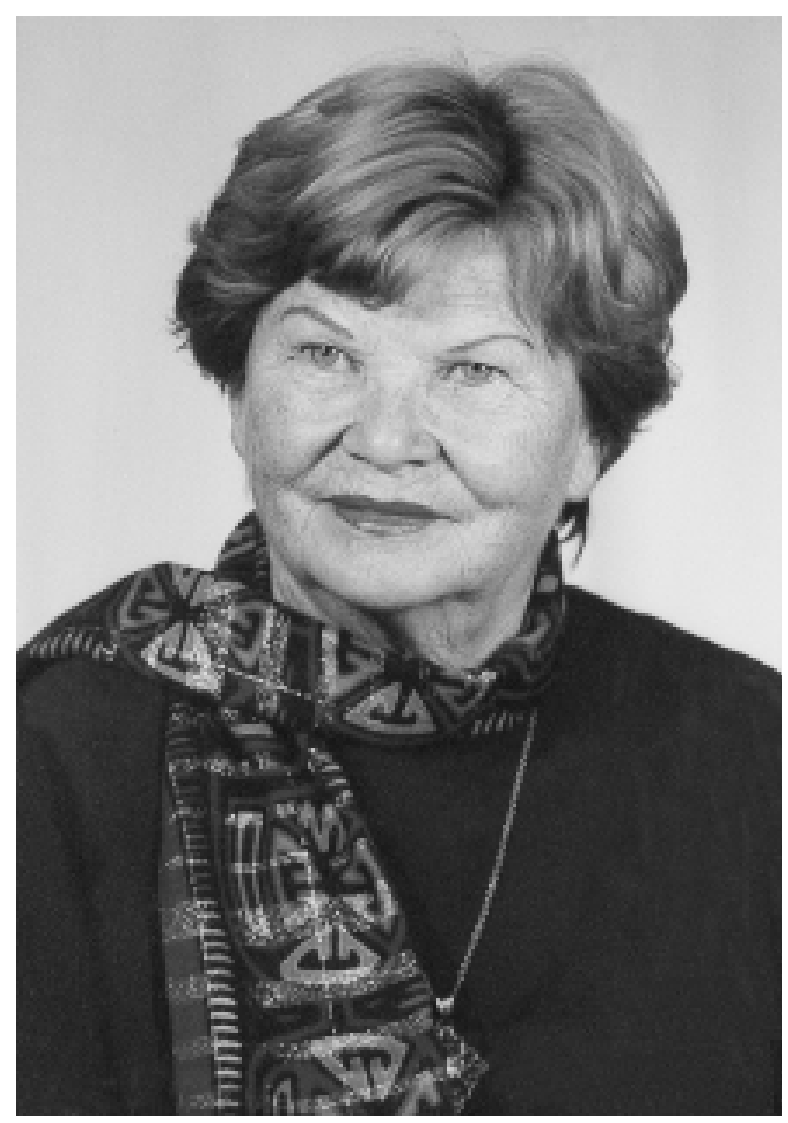

We, botanists and ecologists would like to offer our warm and respectful congratulations to Járainé Komlódi Magda on her anniversary. She was born on 23 February in Battonya. She was a student at Ranolder Teachers' Training College, where her interest in plants was first kindled by her biology teacher, who improved and refined her knowledge of botany. She was raised in difficult circumstances. Her family suffered from economic hardships due to her father's long and serious illness. Her energetic, clever and remarkably clear-headed mother had to take on the role of breadwinner and head of the family. 
Járainé Komlódi Magda enrolled at Pázmány Péter University of Science of Budapest in 1949, where she studied biology and chemistry. Although she was also fascinated by chemistry, she decided on botany. Andreánszky Gábor played a significant role in this decision, who was a professor of botany, excellent at phytogeography and internationally acclaimed in the field of paleobotany. He was a charismatic scholar devoted to his profession, whose love of his subject may have been more striking than other professors'. He had a decisive influence not only on her career, but on her way of thinking as well. He taught her all the nuts and bolts of research. He showed her all the beauty and usefulness of scientific research and of botany. As Járainé Komlódi Magda recalls, "Whenever he found something interesting or unusual in the course of his research or expeditions, he came up with a host of floristic, phytocoenological and ecological arguments to investigate it. He supported his findings with all plausible theses of geography, geology and climatology. He was content with his own claims only if there were various arguments giving a firm grounding to his theories. His whole life, his career as a teacher and researcher were an example of professional as well as human integrity."

Looking back at Járainé Komlódi Magda's life-work of 45 years, her way of thinking, working methods and scientific concepts, it is apparent that she followed Andreánszky's example. This example shows in her articles and her personal relationships alike. She was undoubtedly also influenced by Soó Rezső. By that time, however, her personality was almost completely formed.

She was respected for her expertise already during her studies at university. Her great knowledge of taxonomy gained her distinction among the other students. In 1951, during the third year of her university studies, the training of biologists was introduced at the University of Science of Budapest, by that time named after Eötvös Loránd. Not surprisingly, she was one of the first students accepted. She was given a degree in botany in 1954, but she was not content with it: the very next year she received a diploma as a secondary school teacher of biology and chemistry. She graduated as a researcher as well as a teacher and made ample use of both. However, her fate did not lead her to a secondary school. Her alma mater called her: she was invited by Prof. Soó Rezső to teach at the Department of Phytotaxonomy and Phytogeography. She spent 38 years there, teaching generations of to-be teachers of biology.

She began her career as a phytocoenologist. Right at the beginning she made significant floristic discoveries. Certain species found in the Dan- 
ube-Tisza Interfluve (such as Dryopteris austriaca, Galeobdolon luteum, etc.) pointed to the fact that there used to be stronger montane effects in that region of the Great Hungarian Plain. Her interest was roused by the well-developed fen plant communities characteristic of the area. The best descriptions to date of the vegetation of the Ócsa-Dabas moorlands were constructed at that time, at the end of the 1950s. Even today, they are remarkably modern, with a dynamic aspect, with an outlook on landscape history. To mention an example, she evaluated the effects of the amount of rainfall based on the precipitation regime not on average values. She was also interested in the dynamic relationships of vegetation units; she proposed one of the first succession schemes. Her vegetation descriptions are still used as references in vegetation and landscape historical studies, but are also used for practical purposes, such as in nature conservation or in the wetland program. They prove clearly that reliable vegetation descriptions do not become obsolete. She also described a new fen plant community, giving early proof that the transformation of the area was due to drying out. She established a life-long friendship with the vegetation of fens. This is documented, among others, in her study of the vegetation of Lake Baláta, written together with Borhidi Attila, or in the research she conducted in the Hanság region. Her early research of fens determined the direction of her later work. She was also attracted by the North Hungarian Mountain Range. She is the author of one of the first studies investigating the vegetation of the Gerecse Mountains. Although she later gave up the study of plant communities, her familiarity with coenology acquired in the 1950s and early 1960s gave her firm grounding for the reconstruction of vegetation and vegetation movements in palinology.

Her achievements in taxonomy mainly belong to the field of pollen morphology. This is how her work was linked to Borhidi Attila's systematic research of flowering plants. The result of this co-operation was the discovery of two new genera: Acunaeanthus and Javorkaea. She also studied the morphology of moss spores. Her research on the Encalypta genus shows that the genus, which had earlier been considered uniform, consists of three types, which are easily distinguishable based on the morphology of their spores. Her work on the morphology of moss spores culminated in a book written together with Boros Ádám (two more researchers contributed to the second edition). Plant families widespread throughout Europe or circumboreal ones were chosen for the study. This research is also related to her paleobotanic work, as she came to realise that for an attempt to reconstruct paleoecological conditions, various independent approaches 
are needed. She included mosses in the study, since these organisms are indicative of specific habitats.

Nevertheless, her most significant work was done in the field of classical palinology. At the beginning, she had to construct her own set of palinological implements, which included establishing a large collection of recent pollen types. She published a series of studies and synopses on the vegetation history of the Great Hungarian Plain. She greatly extended the period under examination to include the glacial and interstadial phases. She introduced several methodological innovations. In 1974 she developed a highly original technique in collaboration with Prof. J. Rowley in Stockholm. The essence of the new method is to examine one single pollen grain with reflected light microscope, transmission microscope and electron microscope as well. It is an effective and reliable method which is employed especially in the fine structural analysis of pollen, but it may be used in any field of palinology. Collaborating with the mathematician Fischer János, she was the first to employ mathematical statistical methods to analyse fossilised pollen mixtures in order to distinguish between taxa having very similar pollen, which are therefore difficult to identify. This method led to the first identification of the pollen of Picea omorica in the Pleistocene in Hungary. She introduced the study of the fossilised pollen of herbaceous plants, which enabled far more detailed analyses of pollen spectra, from the point of view of both climatic and vegetation history. This made it possible to identify certain climate indicators. She was the first one to identify the pollen of aquatic plants in Quaternary layers. She proved that contrary to public belief, aquatic plants are important climate indicators, since they react to any improvements of the climate more rapidly than terrestrial plants do. She identified the pollen of several aquatic plants in Hungary. All these innovations contributed to our present knowledge of the climate and vegetation history of the country in the Quaternary period, which is far more differentiated than before. Her work was aided by modern, high-quality "full pollen diagrams", also suitable for statistical analysis, which contained evaluations based on the pollen of trees as well as of 20 families, 27 genera and 37 species of grasses. She contributed to the picture we have today of the cold loess steppe vegetation of the late glacial periods, as well as the warm steppe of the boreal phase, by identifying for the first time the pollen of Ephedra, Armeria, Helianthemum, Sanguisorba, Selaginella, Pleurospermum and other species. She was the first to find data proving the presence of Holocene forest-steppes in the preboreal and boreal periods. She demonstrated that in the preboreal birch forest-steppes of the Great 
Hungarian Plain there were broad-leaved trees as well, such as lime, oak, elm and maple. Also, she was the one to point out the changes in the vegetation of the grasslands of forest-steppes, compared to the late glacial period. Artemisia, Chenopodiaceae and other heliphyton late glacial elements became very rare or disappeared altogether. Meanwhile, grasslands rich in Gramineae become dominant, forming a transitional stage towards warm continental steppes. In the early boreal era Eastern type steppe woodlands, rich in Scotch pine, were probably dominant, which were replaced in the second half of the boreal period by mixed oak steppe woodlands. We are indebted to Járainé Komlódi Magda for the identification of the Hedera, Vitis, Viscum, Ilex species that were crucial in determining the climatic optimum of the Atlantic phase. Among these, the identification of Vitis in the Atlantic phase was a new result in Europe as well, since up to then it had only been found to the south of Hungary, in Italy.

Owing to the broad range of her knowledge, she was frequently asked to collaborate with archaeologists, geologists and geographers. This is how she undertook the palinological analysis of Tata and Vértesszőlös, two world-famous Hungarian palaeoanthropic sites. We were glad to note that by the 1990s she had formed a strong and intimate working relationship with Zólyomi Bálint, one of the great Hungarian doyens of palinology, which lasted until his death in 1997. She established more and more co-operations to ensure the reliability of her results, the spatial and chronological accuracy of her data. There have been few synbiologists who formed co-operations as widely and consistently as she did. She published a series of studies with co-authors she chose expediently, including ecologists, taxonomists, mathematical statisticians, meteorologists, geologists, stratigraphists, historians, palaeontologists.

Public recognition was not slow to come: as early as the 1960s and 70s she became a member of the Quaternary Stratigraphic Committee of the INQUA, and also of the Holocene and Eurosiberian subcommittees. Also, she was a member of the Paleontological Committee of the Hungarian Academy of Science until 1996, and of the Hungarian National Committee of the INQUA. She is the Hungarian contributor of a programme of the European Science Foundation, entitled "European Paleoclimate and Man Since the Last Interglacial".

With the increasing prominence of environmental protection, there was more and more urgent demand for regular aeropalinological research in Hungary, in order to measure the biological pollution of the air. That is, the qualitative and quantitative investigation of harmful pollen and spores 
in the environment became necessary, to prevent illnesses or reduce the number of their occurrences. The conditions for such research were only given from 1989 on: that was the year when an instrument of internationally accepted quality was obtained. She introduced aeropalinology to Hungary in collaboration with Juhász Miklós, who was working at József Attila University in Szeged. It is ten years since they joined the European palinological network. The results of these studies gave detailed data of recent pollen precipitation, which had so far been missing from palinological research of the Quaternary period. This lends support to more reliable palaeopalinological assessment of pollen-analytical results, and to a more realistic evaluation of climate and vegetation history. Information on aeroallergens floating in the air has been vital in the field of medicine. They demonstrated that there are three pollen seasons in Hungary: a spring season, which is characterised mainly by the pollen of amentaceous trees; an extended summer season, lasting from the beginning of May until August, mostly caused by the pollen of grasses, and a late summer - early autumn season, mainly as a result of weed pollen. They also identified what the most important allergenic types of pollen are in Hungary (Poaceae, Artemisia and Ambrosia). With the qualitative and quantitative analysis of the fungus spore and conidium content of the air, conducted in Hungary for the first time, they identified the four most important allergenic fungus spores (these are Cladosporium, Alternaria, Leptosphaeria and Epicoccum). Through a comparison of aeropalinological and meteorological data, the effect of meteorological conditions on the pollen content of the air was demonstrated for the first time in Hungary. Also, the first full Hungarian calendar of pollen and fungus spores was compiled. Side by side with observations of clinicians, they conducted comparative studies of the most important allergenic kinds of pollen and illness symptoms, which contributed to the prevention of allergic illnesses. Needless to say, the range of Járainé Komlódi Magda's co-operations was further widened: she worked together with physicians specialising in allergology, pulmonological and clinical immunology. The international recognition of her work is demonstrated by various appointments, for example, she was elected to be a member of the committee of The International Association for Aerobiology.

In 1992 she undertook a new challenge. Relying on her great experience, she applied for the position of Director of the Department of Botany of the Hungarian Natural History Museum. During the 7 years she spent there, she proved to be a determined and innovative leader. This was the period when the system of funds started flourishing. Partly due to her own 
great renown, she received funding both under her own name and that of the Department of Botany, for the material benefit of the department. Several researchers obtained their academic degrees during that time, thanks to her inspiration. These years were characterised by openness: the public relations of the Department of Botany widened perceptibly. This was shown by a host of professional programmes and social events. Although she had not worked with a collection before, she respected the great "investment" of her predecessors and of famous collectors. She strove with devotion for the further development of the national collection, and for the extension of modern means of storage.

The bibliography of Járainé Komlódi Magda's work bears witness to a highly impressive oeuvre. Its main stations were 1954, the year of her graduation from university, 1958, when she obtained her university doctorate, and 1967, when she was awarded a candidate's degree. However, she had to wait for nearly 30 years for the title of Habilitated Doctor and for that of Academic Doctor. This delay was highly unfair, even though she had long been regarded as an Academic Doctor by her colleagues and friends. It was mentioned at the defence of her doctoral dissertation that the work she presented would have been enough for at least two theses.

How has she been capable of such outstanding results? She is known to be amiable but strict at the same time, as an instructor, as a researcher and in her private life alike. She has been strict in judging others' performance, but most of all, she has been strict with herself. In order to reach these exceptional results, she has always kept to a tight schedule. That is how she has managed to find time for her family, science, teaching, and even for social life and arts.

In these days the gap is increasing between professional researchers and the nature-loving general public. As Juhász-Nagy Pál aptly remarks in one of his studies, the great majority of "experts" or specialists either do not even notice or are bewildered by the emerging renaissance of popular botany, hiking, amateur gardening, and the admiration of plant beauty for its own sake, that is, the popularity of scientia amabilis. Its numerous admirers, quite naturally, care nothing about the specialists' lack of understanding. Járainé Komlódi Magda is definitely one of those who have done the most to bridge this gap. She has always been able to find time to talk about her knowledge and experience, and about the joy botany can give us. This holds for botanical curiosities, the adventures of her journeys, or even accounts of research methods for the general public. She has a special talent for the poetic description of phenomena; for example, the way she writes 
about the rain of pollen whirling about like finely powdered sulphur, shrouding water, rocks and leaves alike. Reading such descriptions one is not surprised that she became a pollen analyst: it is easy to see that the marvellous variety of form of the microscopic world is almost a compelling force for research. She knows that interesting curiosities evoke the desire to know, as it happened in her case. She is a natural blend of a researcher and populariser of science; since the driving force of both activities is curiosity, the admiration of nature and the urge to pass on what you know.

On her anniversary we wish that her dreams may come true. May she carry out the remaining syntheses needed, for example, vegetation historical reconstructions, with the involvement of the greatest range of related sciences. As there is no one who could compete with her capacity to give a comprehensive view of science. May she write many more beautiful and useful books of the wonders of nature. In order to do so, we wish her some more round anniversaries and the best of health.

\section{BIBLIOGRAPHY OF JÁRAINÉ KOMLÓDI MAGDA}

Komlódi, M. (1956): Növények együttélése I. Az élősködés. - Élet és Tudomány 11: 440-443.

Komlódi, M. (1956): Növények együttélése II. Gombagyökér, zuzmó. - Élet és Tudomány 11: 664-667.

Komlódi, M. (1956): Növények együttélése III. A fán lakó növények és növénytársulások. Élet és Tudomány 11: 931-933.

Komlódi, M. (1956): A növények válaszolnak. - Élet és Tudomány 11(35): 1110-1113.

Komlódi, M. (1957): Évszázadok pillanatfelvételben. - Élet és Tudomány 12(6): 172-174.

Komlódi, M. (1957): Florisztikai adatok az ócsa-dabasi turjánvidékról. (Floristische Daten aus dem Torfmoor ("Turján") Distrikt von Ócsa-Dabas). - Bot. Közlem. 47: 81-85.

Komlódi, M. (1958): Otthonunk téli virágdíszei. - Élet és Tudomány 13(45): 1432-1434.

Járai-Komlódi, M. (1958): Die Pflanzengesellschaften in dem Turjángebiet von Ócsa-Dabas (Donau-Theiss Zwischenstromgebiet). - Acta Bot. Acad. Sci. Hung. 4(1-2): 63-92. Tabella I-X.

Járainé Komlódi, M. (1958): A Turjánvidék. (The Turjan-region). - Élővilág 3(4): 7-13.

Komlódi, M. (1958): Adatok a Gerecse növényföldrajzához. - Borbás Vince Pályázat, ELTE, Budapest, $35 \mathrm{pp}$.

Járainé Komlódi, M. (1958): Képek lápvidékeinkről. - Természettud. Közlöny 89(12): 559-561.

Járainé Komlódi, M. (1959): Két hét a Balti-tenger partján. (Two weeks on the Baltic Coasts). - Élővilág 4(4): 3-10.

Járai-Komlódi, M. (1959): Sukzessionsstudien an Eschen-Erlenbruchwäldern des DonauTheiss Zwischenstromgebiets. - Ann. Univ. Sci. Budapest., Sect. Biol. 2: 113-122.

Borhidi, A. \& Járai-Komlódi, M. (1959): Die Vegetation des Naturschutzgebietes des Baláta Sees. - Acta Bot. Acad. Sci. Hung. 5(3-4): 259-320.

Borhidi, A. \& J. Komlódi, M. (1959): A csapadék- és vízszint-ingadozás összefüggése a Baláta-tó természetvédelmi területén. (Zusammenhang der Niederschlags- und Was- 
serstandsfluktuation auf dem Naturschutzgebiet des Baláta-Teiches). - Időjárás 63(4): 225-229.

Borhidi, A. \& J. Komlódi, M. (1960): A Baláta-tó növényvilága. - Természettud. Közlöny 91(11): 501-503.

Járai-Komlódi, M. (1960): Beiträge zur Kenntnis der Vegetation des Moorgebiets Hanság. Annales Univ. Sci. Budapest., Sect. Biol. 3: 229-234.

Járainé Komlódi, M. (1961): Amiról a lápok mesélnek. - Búvár Könyvek, Móra Könyvkiadó, Budapest, 164 pp.

Járai Miklósné Komlódi, M. (1962): A vadkender és társulásviszonyai. - In: Mándy, Gy. \& Bócsa, I. (szerk.): Magyarország kultúrflórája VII/14. A kender. Cannabis sativa L. Akadémiai Kiadó, Budapest, pp. 7-9.

Fekete, G. \& Járai-Komlódi, M. (1962): Die Schuttabhangwälder der Gerecse- und Bakony-Gebirge. - Annales Univ. Sci. Budapest., Sect. Biol. 5: 115-129.

Járainé Komlódi, M. (1964): Trópusi vegetációtanulmányok Kubában. (Studies on tropic vegetation in Cuba). - Bot. Közlem. 51(2-3): 143-168.

Járainé Komlódi, M. (1964): A tengerpart és mocsárvilág növényzete Kubában. (Study-tour in Cuba). - Élővilág 9(3): 3-13.

Járai-Komlódi, M. (1964): Die palynologischen Untersuchungen. - In: Vértes, L. (ed.): Tata, eine mittelpaläolithische Travertin-Siedlung in Ungarn. Archaeologia Hung., Ser. Nova 43: 67-77.

Járai-Komlódi, M., Skoflek, I. \& Stieber, J. (1964): Die stratigraphische Wertung der Botanischen Beobachtungen. - In: Vértes, L. (ed.): Tata, eine mittelpaläolithische Travertin-Siedlung in Ungarn. Archaeologia Hung., Ser. Nova 43: 83-86.

Horánszky, A. \& Járainé Komlódi, M. (1964): Növényrendszertani gyakorlatok. - Egyetemi jegyzet, Tankönyvkiadó, Budapest, 79 pp.

Járainé Komlódi, M. (1966): Palinológiai vizsgálatok a Magyar Alföldön a Würm glaciális és a holocén klima- és vegetációtörténetére vonatkozóan. - Kandidátusi értekezés. Kézirat, 280 pp., 84 tábl.

Járainé Komlódi, M. (1966): Palinológiai vizsgálatok a Magyar Alföldön a Würm glaciális és a holocén klíma- és vegetációtörténetére vonatkozóan. - Kandidátusi értekezés tézisei. Kézirat, 13 pp.

Járainé Komlódi, M. (1966): Adatok az Alföld negyedkori klíma- és vegetációtörténetéhez. I. A vegetáció változása a Würm glaciális és a holocén folyamán, palinológiai vizsgálatok alapján. (Quaternary climatic changes and vegetational history of the Great Hungarian Plain. I). - Bot. Közlem. 53(3): 191-201.

Járai-Komlódi, M. (1966): Études palynologiques des couches de la dernière époque glaciaire (Brorup, pléniglaciaire) de la Grande Plaine Hongroise. - Pollen et Spores 8(3): 479-496.

Soó, R., Horánszky, A. \& Járai-Komlódi, M. (1966): Über einige Formenkreise der ungarischen und karpatischen Flora V. - Annales Univ. Sci. Budapest., Sect. Biol. 8: 309-313.

Horánszky, A. \& Járainé Komlódi, M. (1967): Növényrendszertani gyakorlatok. - Egyetemi jegyzet, Tankönyvkiadó, Budapest, 253 pp.

Járai-Komlódi, M. (1968): The Late Glacial and Holocene flora of the Hungarian Great Plain. - Annales Univ. Sci. Budapest., Sect. Biol. 9-10: 199-225.

J. Komlódi, M. (1969): A természetes növénytakaró kialakulásának rövid története. Dabas. - In: Simon, T. (szerk.): Növényrendszertani terepgyakorlatok. Egyetemi jegyzet, Tankönyvkiadó, Budapest, pp. 15-19, 39-44. 
Járainé Komlódi, M. (1969): Adatok az Alföld negyedkori klíma- és vegetációtörténetéhez. II. (Quaternary climatic changes and vegetational history of the Great Hungarian Plain. II). - Bot. Közlem. 56: 43-55.

Fischer, J. \& Járainé Komlódi, M. (1970): Fosszilis keverék pollenek azonosításának matematikai módszere a Picea omorika és Picea abies esetében. (A mathematical method of identifying fossil pollen grains on Picea omorika and Picea abies). - Bot. Közlem. 57: 59-68.

Járai-Komlódi, M. (1970): Studies on the vegetational history of Picea omorika Panc. on the Great Hungarian Plain. - Annales Univ. Sci. Budapest., Sect. Biol. 12: 143-156.

Járai-Komlódi, M. (1970): Beiträge zum Spätglazial in Ungarn. - In: Kliewe, H. (ed.): Probleme der Weichsel-Spätglazialen Vegetationsentwicklung in Mittel- und Nordeuropa. Frankfurt/Oder., pp. 124-138.

Járainé Komlódi, M. (1971): A pleisztocén kronológiájának és a pliocén-pleisztocén határnak néhány problémája. (Some questions of the Pleistocene chronology and the Plio-Pleistocene boundary). - Bot. Közlem. 58(3): 131-143.

Járai-Komlódi, M. \& Simon, T. (1971): Palynological studies on swamps of the Zemplén Mountains. - Annales Univ. Sci. Budapest., Sect. Biol. 13: 103-113.

Járainé Komlódi, M. (1971): Modern módszerek és új eredmények a pleisztocén kutatásában. - Természet Világa 102(12): 535-539, 543.

Járai-Komlódi, M. (1972): Role and importance of Pleistocene and Holocene palynology. Abstracts, Refresher Colloquium 1971 in the fields of stratigraphy and micropalaeontology. Jahrbuch der Geologischen Bundesanstalt Sonderband 19: 38.

Járai Miklósné (1972): A Velencei-tó iszaprétegeinek pollenstatisztikai vizsgálata. (Pollenstatistical studies on the Lake Velence in Hungary). - In: Baranyi (szerk.): Tájékoztató az állóvizek hidrológiai feltárásáról 1970. VITUKI, Budapest, pp. 64-67.

Járainé Komlódi, M. (1973): Eurázsia felső-pleisztocén vegetációja a Würm glaciális hideg maximuma és a Riss-Würm interglaciális klímaoptimuma idején. - MTA X. Oszt. Közlem. 6: 173-181.

Járainé Komlódi, M. \& Járai, M. (1973): Természeti képek Japánból. (Landscape pictures from Japan). - Természet Világa 104(11): 485-489.

Járai-Komlódi, M. (1973): Pollenstatistical examinations of the travertine layers of the palaeolithic site at Vértesszőllős. - Földrajzi Közlem. 2: 120-132.

Járainé Komlódi, M. (1974): Címszavak. - In: Szende, K. (szerk.): A modern biológia címszavakban. Natura, Budapest, 456 pp.

Járai-Komlódi, M. (1974): Comparative spore morphological examinations in Funaria and Physcomitrium species. - Acta Bot. Acad. Sci. Hung. 20: 71-81.

Dobosi, Z. \& Járai-Komlódi, M. (1974): Investigations on the Upper Pleistocene Albedo of Eurasia. - Acta Geol. Acad. Sci. Hung. 18: 91-98.

Boros, Á. \& Járai-Komlódi, M. (1975): An atlas of recent European moss spores. - Akadémiai Kiadó, Budapest, 465 pp.

Járainé Komlódi, M. (1975): Vegetációtörténeti címszavak. - In: Straub, F. B. (szerk.): Biológiai Lexikon I-IV. 1975-1978. Akadémiai Kiadó, Budapest.

Járainé Komlódi, M. (1975): Botanikus szemmel a sarkkörön túl. - Természet Világa 106(7): 296-299.

Járai Miklósné (1975): Természetvédelem Svédországban. (Nature protection in Sweden). Búvár 30(5): 203-208.

Járainé Komlódi, M. (1975): Botanikai tanulmányúton Svédországban I. 200 kilométerrel az északi sarkkör fölött. (Botanical excursions in Sweden. I). - Bot. Közlem. 62: 39-44(-48). 
Járai-Komlódi, M. \& Orbán, S. (1975): Spore morphological studies on recent European Encalypta species. - Acta Bot. Acad. Sci. Hung. 21(3-4): 305-345.

Rowley, J. R. \& Járai-Komlódi, M. (1976): Observation of the pollen grain by SEM, TEM, and light microscopy. - Acta Bot. Acad. Sci. Hung. 22(3-4): 449-461.

Járai-Komlódi, M. (1977): Úton Mexikó természeti tájain. - Búvár 32: 74-78.

Járainé Komlódi, M. (1977): Botanikai tanulmányúton Svédországban II. Öland szigete. (Phytogeographical excursion in Sweden. II. On the Baltic island of Öland). - Bot. Közlem. 64: 221-226.

Járai-Komlódi, M. (1977): Recensiones. - Acta Bot. Acad. Sci. Hung. 23: 440-442.

Járainé Komlódi, M. \& Bíró, K. (1978): Kultúrnövények 2. A mérsékelt öv termesztett növényei.Búvár zsebkönyvek, Móra Könyvkiadó, Budapest, 63 pp.

Járainé Komlódi, M. (1978): Egy pusztulásra ítélt arborétum megmentéséért. - Búvár 33(11): 520-521.

Járai-Komlódi, M. (1979): Recensiones. - Acta Bot. Acad. Sci. Hung. 25: 427-428.

Járainé Komlódi, M. \& Lexáné Regéczy M. (1980): Füszernövények. - Búvár zsebkönyvek, Móra Könyvkiadó, Budapest, 64 pp.

Járainé-Komlódi, M. (1980): Módszertani tanulmány Linum virágporszemeken fény (LM) és elektronmikroszkóppal (TEM, SEM) történő összehasonlító vizsgálatokhoz. (A methodological study for comparative examinations in pollen grains of Linum by mean of light-(LM) and electron (TEM, SEM) microscopes). - Bot. Közlem. 67:37-47.

Borhidi, A., Járai-Komlódi, M. \& Moncada, M. (1980): Acunaeanthus, a new genus of Rubiaceae. - Acta Bot. Acad. Sci. Hung. 26(3-4): 277-287.

Járainé-Komlódi, M. (1980): Botanikai tanulmányok Mexikóban I. (Botanical studies on the vegetation of Mexico. I). - Bot. Közlem. 67: 219-225.

Járainé-Komlódi, M. (1981): Botanikai tanulmányok Mexikóban II. (Botanical studies on the vegetation of Mexico. II).- Bot. Közlem. 68: 19-28.

Járainé-Komlódi, M. (1981): Botanikai tanulmányok Mexikóban III. (Botanical studies on the vegetation of Mexico. III).- Bot. Közlem. 68: 51-58.

Járainé Komlódi, M. (1981): Variációk a megporzásra. - Természet Világa 112(6): 269-270.

Járainé Komlódi, M. (1982): A növényvilág fejlődéstörténete. - In: Vida, G. (szerk.): Evolúció II. Az élővilág evolúciója. Natura, Budapest, pp. 37-110.

Járainé Komlódi, M. (1982): A palinológia helye a régészeti kutatásban. - Magyar Nemzeti Múzeum, Budapest, Régészeti Továbbképzó Füzetek 1: 31-38.

Járainé Komlódi, M., Kordos, L. \& Tardy, J. (1982): Kronológia. - In: Tardy, J. (szerk.): Bevezetés a magyar őstörténet kutatásának forrásaiba IV. Történeti természettudományok és térképi források. Tankönyvkiadó, Budapest, pp. 9-22.

Járainé Komlódi, M., Kordos, L. \& Tardy, J. (1982): Kormeghatározásimódszerek. - In: Tardy, J. (szerk.): Bevezetés a magyar őstörténet kutatásának forrásaiba IV. Történeti természettudományok és térképi források. Tankönyvkiadó, Budapest, pp. 23-43.

Járainé Komlódi, M. (1982): Történeti növényföldrajz. - In: Tardy, J. (szerk.): Bevezetés a magyar őstörténet kutatásának forrásaiba IV. Történeti természettudományok és térképi források. Tankönyvkiadó, Budapest, pp. 129-189.

Járai-Komlódi, M. (1983): Book Reviews. - Acta bot. hung. 29: 394-396.

Borhidi, A. \& Járai-Komlódi, M. (1983): Studies in Rondeletieae (Rubiaceae) IV. A new genus: Javorkaea. - Acta bot. hung. 29(1-4): 13-27.

Járainé Komlódi, M. \& Vida, G. (1983): A bioszféra evolúciója. - In: Vida, G. (szerk.): Evolúció III. Evolúció és az emberiség. Natura, Budapest. pp. 11-83. 
Járainé Komlódi, M. (1984): Kukoricaisten gyermekei. - Világjárók 158, Gondolat, Budapest, $343 \mathrm{pp}$.

Járainé Komlódi, M. (1985): Pollenanalitikai vizsgálatok a Kolon-tónál. - In: Tóth, K. (szerk.): Tudományos kutatások a Kiskunsági Nemzeti Parkban (1975-1984). Hungexpo, Budapest, pp. 152-155.

Járainé Komlódi, M. (1986): Virágporszemtan (palinológia). - In: Terpó, A. (szerk.): Növényrendszertan az ökonómbotanika alapjaival. I. Mezőgazdasági Kiadó, Budapest, pp. 23-32.

Járai-Komlódi, M. (1987): Postglacial climate and vegetation history in Hungary. - In: Pécsi, M. \& Kordos, L. (eds): Holocene environment in Hungary. Geogr. Res. Inst., Hung. Acad. Sci., Budapest, pp. 37-47.

Járainé Komlódi, M. (1987): Legendás növények. - Gondolat zsebkönyvek, Gondolat Könyvkiadó, Budapest, 128 pp.

Járainé Komlódi, M. (1988): A trópusi őserdők jelene és jövője. - Természet Világa 119(5): 223-224.

Kordos, L. \& Járai-Komlódi, M. (1988): Az elmúlt tízezer év klímaváltozásai Közép-Európában. - Idojjárás 92: 96-100.

Járainé Komlódi, M. \& Gondár, I.-né (1988): Virágporszem-allergia. Mi okozza a szénanáthát?- Természet Világa 119(6): 251-254.

Járainé Komlódi, M. \& Gondár, I.-né (1988): Virágporszem-allergia (II). - Természet Világa 119(9): 412-415.

Járainé Komlódi, M. (1988): Pollenháború. Képeskönyv a világhódító virágporról. - Móra Ferenc Könyvkiadó, Budapest, 132 pp.

Járainé Komlódi, M. (1989): Gyógynövények, növényi orvosságokés alkalmazásuk a mexikói népi orvoslásban. - In: Babulka, P., Boksányi, L. \& Grynaeus, T. (szerk.): Síppal, dobbal... (Hagyományos orvoslás az Európán kívüli népek körében). Mezőgazdasági Könyvkiadó, Budapest, pp. 131-143.

Járainé Komlódi, M. (1989): Gondolatok és tervek a levegő pollenszennyeződésének kutatásáról. Előadás és poszter kivonatok, A Magyar Allergológiai és Klinikai Immunológiai Társaság (MAKIT) XVII. Vándorgyúlése, Eger, pp. 20-21.

Mezei, Gy., Járainé Komlódi, M., Cserháti, E. \& Kelemen, J. (1989): A hobbiállat tartás indirekt allergénforrásai. - Előadás és poszter kivonatok, A Magyar Allergológiai és Klinikai Immunológiai Társaság (MAKIT) XVII. Vándorgyúlése, Eger, p. 25.

Járainé Komlódi, M. \& Bíró, K. (1989): Kultúrnövények 3. Idegen tájak termesztett növényei. Búvár zsebkönyvek, Móra Könyvkiadó, Budapest, 63 pp.

Járainé Komlódi, M. \& Mezei, Gy. (1989): Hobbiállat! Pollenallergia? - Természet Világa 120(9): 410-411.

Járai-Komlódi, M. \& Mezei, Gy. (1989): Allergen pollen in the food of pet animals. Abstracta Bot. 13: 67-86.

Járainé Komlódi, M. (1990): Növényi csodák. - Gondolat zsebkönyvek, Gondolat Könyvkiadó, Budapest, 128 pp.

Járainé Komlódi, M. (1990): Allergén virágporszemek. - Élet és Tudomány 45(14): 428-429.

Járainé Komlódi, M. (1990): Allergén virágporok. Az éger. - Élet és Tudomány 45(15): 467.

Járainé Komlódi, M. (1990): Allergén virágporok. A mogyorófélék. - Élet és Tudomány 45(17): 531.

Járainé Komlódi, M. (1990): Allergén virágporok. A ciprusfélék. - Élet és Tudomány 45(19): 595.

Járainé Komlódi, M. (1990): Allergén virágporok. A nyárfa. - Élet és Tudomány 45(21): 659. 
Járainé Komlódi, M. (1990): Allergén virágporok. A kőrisfa. - Élet és Tudomány 45(23): 723. Járainé Komlódi, M. (1990): Allergén virágporok. A fúz. - Élet és Tudomány 45(25): 787. Járainé Komlódi, M. (1990): Allergén virágporszemek. A nyír. - Élet és Tudomány 45(27): 851. Járainé Komlódi, M. (1990): Allergén virágporszemek. A bükkfafélék. - Élet és Tudomány 45(29): 915.

Járainé Komlódi, M. (1990): Allergén virágporszemek. A juharfélék. - Élet és Tudomány 45 (31): 979.

Járainé Komlódi, M. (1990): Allergén virágporszemek. A szil- és platánfélék. - Élet és Tudomány 45(33): 1043.

Járainé Komlódi, M. (1990): Allergén virágporszemek. A füvek. - Élet és Tudomány 45(35): 1107.

Járainé Komlódi, M. (1990): Allergén virágporszemek. A pillangósvirágúak. - Élet és Tudomány 45(37): 1171.

Járainé Komlódi, M. (1990): Allergén virágporszemek. A nyári gyomok. - Élet és Tudomány 45(39): 1235.

Járainé Komlódi, M. (1990): Allergén virágporszemek. Nyári-őszi gyomok. - Élet és Tudomány, 45(41): 1299.

Járainé Komlódi, M. (1990): Allergén virágporszemek. Az üröm és más fészkesek. - Élet és Tudomány 45(43): 1363.

Járainé Komlódi, M. (1990): Allergén virágporszemek. A hírhedt “vadkender”. - Élet és Tudomány 45(45): 1427.

Mezei, Gy., Járainé Komlódi, M. \& Cserháti, E. (1990): Allergén virágporszemek lakásban tartott állateleségekben. (Allergen pollens in food of indoor pet animals). - Medicina Thoracalis (Pneumonologia Hungarica) 43: 199-210.

Járainé Komlódi, M. (1990): Növények küldöttei. - Süni (Természettudományokról fiataloknak), 6(5): 6-7.

Járai-Komlódi, M. (1990): Pollen-statistical analyses from the Vértesszőlős travertine. - In: Kretzoi, M. and Dobosi, T. V. (eds): Vértesszőlős, site, man and culture. Akadémiai Kiadó, Budapest, pp. 125-135.

Mezei, Gy., Járai-Komlódi, M. \& Cserháti, E. (1990): Pet food as an unusual source of indoor pollen allergy. (Abstract). - Clin. Exper. Allergy 20(Suppl. 1): 69.

Horánszky, A. \& Járainé Komlódi, M. (1991): Növényrendszertani praktikum. - Tankönyvkiadó, Budapest, 549 pp.

Járainé Komlódi, M. (1991): Magyarország pleisztocénvégi vegetációtörténete az utolsó interglaciális óta. (Vegetation history of the Hungarian Late Pleistocene since the last interglacial). - Öslénytani viták (Discussiones Palaeontologicae) 36-37: 201-215.

Járai-Komlódi, M. (1991): First results of a study on airborne sporomorphs in Budapest, Hungary. - Grana 30: 464-466.

Járainé Komlódi, M. \& Barabás, É. (1991): Allergén gombaspórák és konídiumok magevő kisállatok eleségében. (Allergen fungal spores and conidia in the food of pets). Abstracta Bot. 15: 99-103.

Járai-Komlódi, M. (1991): Airborne grass pollen data in Budapest 1991. - In: Jäger, S. \& Mandrioli, P. (eds): Airborne grass pollen distribution in Europe 1991. Aerobiologia, Special Issue, 7: 7-29.

Mezei, Gy., Járainé Komlódi, M., Bodor, G. \& Cserháti, E. (1991): A levegő pollentartalmának és az allergiás rhinitises betegek tüneteinek összefüggése parlagfú szezonban. (Correlation between concentrations of aeropollens and symptoms of allergic rhinitis patients during ragweed season). - Medicina Thoracalis 44(11): 471-476. 
Járai-Komlódi, M. (1991): Late Pleistocene vegetation history in Hungary since the Last Interglacial. - In: Pécsi, M. \& Schweitzer, F. (eds): Quaternary environment in Hungary. Studies in geography in Hungary 26. Akadémiai Kiadó, Budapest, pp. 35-46.

Járainé Komlódi, M. \& Juhász, M. (1991): A parlagfü (Ambrosia elatior L.) Magyarországon. Abstracts, MAKIT XIX. Vándorgyûlése, Győr, p. 13.

Juhász, M. \& Járainé Komlódi, M. (1991): Pollinózist okozó nyárvégi gyomok. - Abstracts, MAKIT XIX. Vándorgyúlése, Győr, p. 14.

Mezei, Gy., Járai-Komlódi, M., Papp, E. \& Cserháti, E. (1992): Late summer pollen and allergen spectrum in children with allergic rhinitis and asthma in Budapest. (Abstract). Pädiatrie und Pädologie 27(3): 75.

Járainé Komlódi, M. (1992): A növényvilág matuzsáleme, a szálkásfenyő. - Természet Világa 123(7): 321-322.

Mezei, Gy., Járai-Komlódi, M., Bodor, G. \& Cserháti, E. (1992): The two main pollen seasons in Hungary. (Abstract). - Allergy 47(12) (Suppl.): 313.

Járai-Komlódi, M., Tóth, S. \& Barabás, É. (1992): Studies on rare airborne fungal spores and conidia in Hungary 1990. - Program and Abstracts, 8th Intern. Palynol. Congr., Aix-enProvence, p. 72.

Járai-Komlódi, M. \& Juhász, M. (1992): The aeroallergenic significance of autumn weeds, particularly of ragweed, in Hungary. - Program and Abstracts, 8th Intern. Palynol. Congr., Aix-en-Provence, p. 72.

Járai-Komlódi, M., Tóth, S. \& Barabás, É. (1992): Comparisons with athmospheric concentration data of allergenic microfungi according to three-years daily measurements in Hungary 1988-1991. - Abstracts, 8th Intern. Congress of Immunology, Budapest. Springer Kiadó, Budapest, p. 462.

Járai-Komlódi, M. (1992): Book Reviews. - Acta bot. hung. 37: 422.

Járai-Komlódi, M. \& Medzihradszky, Zs. (1993): Aeropollen research in the air of Budapest in 1992. - Studia bot. hung. 24: 45-49.

Járai-Komlódi, M. \& Medzihradszky, Zs. (1993): Aero adatbázis HUBIIF11. - IIF. HU BRS/Search.

Járai-Komlódi, M. \& Juhász, M. (1993): Ambrosia elatior (L.) in Hungary (1989-1990). Aerobiologia 9: 75-78.

Járai-Komlódi, M. (1993): A növénytakaró változatossága. Puszta-e a puszta? Ritkaságaink megóvása, természetvédelem. Virágtalan növényeink. Magvas, virágos növények. Erdőségeink. Vizeink növényzete. Virágos rétek, fátlan gyepek növényzete. A magyar flórakincs és növényzet eredete. - In: Halmos, F. (szerk.): Pannon Enciklopédia: A magyarság kézikönyve. Pannon Könyvkiadó, Budapest, pp. 66-85.

Járainé Komlódi, M. (1993): Aeropalinológiai vizsgálatok Pakson, különös tekintettel a parlagfúre és más, allergiát okozó virágporszemekre és spórákra. (Pollen monitoring in Paks (Hungary) and detailed information about Ambrosia, and the most allergenic pollen). - Bot. Közlem. 80: 151-161.

Boros, Á., Járai-Komlódi, M., Tóth, Z. \& Nilsson, S. (1993): An atlas of recent European bryophyte spores. Scientia Publishing, Budapest, 321 pp.

Járainé Komlódi, M. \& Medzihradszky, Zs. (1994): Budapesti Pollenallergia Kalauz. - OTKA E 12169, Budapest, 74 pp.

Járainé Komlódi, M. \& Buczkó, K. (1994): Növénypanoptikum. - Élet és Tudomány, 49: 527-529. 
Járainé Komlódi, M. \& mtsai (1994): Az élővilág állapota: Helyzetkép és célok. - In: MTA TKKK (ed.): Magyarország környezeti jövőképe. MTA és Környezetvédelmi és Területfejlesztési Minisztérium, Budapest, pp. 32-38.

Járai-Komlódi, M. (1994): Átlagos pollen-előfordulás Budapesten (1989-1993) II-XI. hó között. - Gyermekgyógyászat 45(3): 242.

Járai-Komlódi, M. (1994): Biological airpollution. Aeropalinological studies in Hungary. - Abstracts, XXIst Congress of the Hungarian Biological Society, Pécs, p. 32.

Járai-Komlódi, M., Mezei, Gy., Medzihradszky, Zs. \& Cserháti, E. (1994): Role of pollen allergy in children suffering from allergic rhinitis/conjunctivitis. - Abstracts, EAACI '94, XV Int. Congr. of All. and Clin. Imm., Stockholm. Allergy and Clinical Immunology News, (Suppl. 2): 465.

Dervaderics, M., Lantos, A., Zsiray, M. \& Járai-Komlódi, M. (1994): Follow up study of allergic patients in the neigborhood of power station in Hungary. (Abstract). - Tubercle and Lung Disease, 75(Suppl. 1): 126.

Járai-Komlódi, M. \& Medzihradszky, Zs. (1994): Five years aeropalynological results in Hungary. - Abstracts, 5th International Conference on Aerobiology, Bangalore, India, p. 54.

Mezei, Gy., Járai-Komlódi, M., Medzihradszky, Zs. \& Cserháti, E. (1994): Pollen allergy in Hungary based on a five years comparative study. - Abstracts, 5th International Conference on Aerobiology, Bangalore, India, p. 49.

Járainé Komlódi, M. \& Medzihradszky, Zs. (1994): Pollenkalendáriumi adatok. - Bot. Közlem. 81(1): 107-108.

Járainé Komlódi, M. (1994): Az ételallergia kiváltásában szerepet játszó néhány fontos növény botanikai jellemzői. - In: Nékám, K. \& Szemere P. (szerk.): Táplálkozási allergiák. Springer Verlag, Budapest, Berlin, Heidelberg, New York, London, Paris, Tokyo, Hong Kong, Barcelona, pp. 139-158.

Mezei, Gy., Járai-Komlódi, M. \& Cserháti, E. (1994): Pet food as an unusual source of indoor pollen allergy. - Acta Paediat. Hung. 34: 73-80.

Járai-Komlódi, M. \& Tóth, S. (1994): Studies on rare airborne fungal spores and conidia in Hungary. - Acta bot. hung. 38(1-4): 283-299.

Mezei, Gy., Járai-Komlódi, M., Medzihradszky, Zs. \& Cserháti, E. (1995): Pollenallergy in Hungary based on a five years-comparative study. - Abstracts, IV Semmelweis Science Fair, Budapest, p. 33.

Medzihradszky, Zs. \& Járai-Komlódi, M. (1995): I came from America-my name is Ambrosiasome feature of the ragweed. - Proceedings, 9th EWRS Symposium, "Challenges for weed science in a changing Europe", European Weed Research Society, Budapest, pp. 57-63.

Járainé Komlódi, M. (1995): Mit kell tudnunk a pollenallergiáról, és mit kell tennünk? - Új Pedagógiai Szemle 45: 40-49.

Járainé Komlódi, M. (1995): Allergizáló virágporszemek és az azokat termelő legfontosabb növények. Pollennaptár. - In: Kovács, I., Kósa, L. \& Schweiger, O. (szerk.): A légúti betegségekről. Az Asztmás Gyermekek Korszerú Kezeléséért Alapítvány, Budapest, pp. 239-247.

Mezei, Gy., Járainé Komlódi, M., Medzihradszky, Zs. \& Cserháti, E. (1995): Szezonális allergiás rhinitis- és pollenszám (Ötéves felmérés Budapesten). (Seasonal allergic rhinitis and pollen count). - Orvosi Hetilap 136(32): 1721-1724.

Járainé Komlódi, M. (1995): Újjáéledés a jégkorszak után. A puszták világa. Ember és természet. Paleobotanikai múhely. Feltámasztott tanúk. - In: Járainé Komlódi, M. (főszerk.): Pannon Enciklopédia: Magyarország növényvilága. Dunakanyar 2000 Kiadó, Budapest, pp. 42-51. 
Járainé Komlódi, M. (1995): Allergiát okozó növények. - In: Járainé Komlódi, M. (főszerk.): Pannon Enciklopédia: Magyarország növényvilága. Dunakanyar 2000 Kiadó, Budapest, pp. 268-289.

Mezei, Gy., Járainé Komlódi, M., Miriszlay, E., Medzihradszky, Zs., Csapó, S. \& Cserháti, E. (1995): Az allergiás náthások tüneti válasza a légköri "virágpollen szennyeződésre" (5 éves epidemiológiai vizsgálat). - In: Schweiger, O. \& Szabó, T. (szerk.): Környezeti ártalmak és a légzőrendszer. 5: 109-110.

Fehér, Z., Járainé Komlódi, M. \& Gallowich, E. (1995): Aeropalinológiai monitorozás az Abaligeti-barlangban. (Abstract). - MAKIT XXIII. Kongresszus, Budapest. Medicina Thoracalis Suppl. 43.

Járai-Komlódi, M., Bajzáth, J., Medzihradszky, Zs., Dömsödi, J. \& Hertelendi, E. (1995): Reconstruction of the past plant communities based on palynological and macrofossil analysis in Transdanubia, Hungary. - Abstracts, European Research Conferences: The ecological setting of Europe: from the past to the future. The establishment of plant and animal communities in Europe since the last glaciation. La Londe les Maures, France, p. 59.

Járainé Komlódi, M. (1995): Paleo- és recens palinológiai tanulmányok és rendszeres aeropalinológiai vizsgálatok Magyarországon. - Doktori értekezés tézisei, Budapest. Kézirat, 14 pp.

Járainé Komlódi, M. (1996): Az MTM Növénytárának kutatásai a Kiskunsáoi Nemzeti Park területén. - In: Tóth, K. (szerk.): 20 éves a Kiskunsági Nemzeti Park 1975-1995. Kiskunsági Nemzeti Park Igazgatósága, Kecskemét; pp. 121-144.

Járainé Komlódi, M. (1996): A dél-amerikai araukáriák. - Természet Világa 127(7): 328-331.

Járainé Komlódi, M. (1996): Előszó. - Emlékkötet Andreánszky Gábor (1895-1967) születésének 100. évfordulójára. Studia Naturalia 9: 7-9.

Medzihradszky, Zs. \& Járainé Komlódi, M. (1996): Az ember természetformáló tevékenysége a holocén folyamán a Kárpát-medencében. (The influence of human activities on the environment in the Carpathian Basin during the Holocene). - Studia Naturalia 9: 147-154.

Juhász, M. \& Járai-Komlódi, M. (1996): 7-year study of airborne ragweed pollen in Hungary. (Abstract). - XVII. European Congress of Allergology and Clinical Immunology, Budapest, Allergy 51(Suppl.): 190.

Fehér, Z., Járai-Komlódi, M. \& Gallovich, E. (1996): Aeropalynological monitoring in the Abaliget-cave, Hungary. (Abstract). - XVII. European Congress of Allergology and Clinical Immunology, Budapest, Allergy 51(Suppl.)(31): 644.

Mezei, Gy., Járai-Komlódi, M., Jacobsen, L., Lowenstein, H., Medzihradszky, Zs. \& Cserháti, E. (1996): Ragweed allergy in Hungarian children. (Abstract). - XVII. European Congress of Allergology and Clinical Immunology, Budapest. Allergy 51(Suppl.): 144.

Juhász, M. \& Járainé Komlódi, M. (1996): A hazai fák tavaszi allergén pollentermelése. - In: Szabó, T. \& Miriszlai, E. (szerk.): Környezeti ártalmak és a légzőrendszer. 6: 78-87.

Medzihradszky, Zs. \& Járai-Komlódi, M. (1996): Late Holocene vegetation history and the activity of man in the Tapolca Basin. - Annls hist.-nat. Mus. natn. hung. 88: 21-29.

Fehér, Z. \& Járai-Komlódi, M. (1996): Relationship between the airborne ragweed pollen concentration and the macrosynoptic weather types in Budapest, Hungary. - Ann. Agric. Environ. Med. 3: 121-126.

Mezei, Gy., Cserháti, E. \& Járai Komlódi, M. (1997): Haustierfutter als seltene Ursache von "Indoor"-Pollenallergie. (Pet food as an unusual source of indoor pollen allergy). Atemw.-Lungenkrkh. 23(Suppl. 1): 575-576.

Járainé Komlódi, M. (1997): Pollennaptár. - Recept nélkül (Egészségvédelmi folyóirat) 2(5): 16-17. 
Juhász, M., Járai-Komlódi, M., Kadocsa, E., Mezei, Gy. \& Juhász, M. (1997): Grass pollen allergy in Hungary. (Abstract). - EAACI'97 meeting, Rhodes, Hellas. Allergy 52(Suppl.): 57.

Mezei, Gy., Veres, A., Medzihradszky, Zs., Járai-Komlódi, M. \& Cserháti, E. (1997): Tree pollen allergy in children with allergic rhinoconjunctivitis. (Abstract). - EAACI'97 meeting, Rhodes, Hellas. Allergy 52(Suppl.): 140.

Mezei, Gy., Járai-Komlódi, M., Medzihradszky, Zs. \& Cserháti, E. (1997): Pollen allergy in Hungary based on a five years comparative study. - In: Agashe, S. N. (ed.): Aerobiology. Oxford \& IBH Publishing, Calcutta, pp. 369-374. (5th International Aerobiology Conference, Bangalore, 1994).

Járai-Komlódi, M. \& Medzihradszky, Zs. (1997): Five years airborne pollen monitoring in Hungary (1989-1993). - In: Agashe, S. N. (ed.): Aerobiology. Oxford \& IBH Publishing, Calcutta, pp. 389-398. (5th International Aerobiology Conference, Bangalore, 1994).

Bodor, E., Járai-Komlódi, M., Medve, A. \& Cserny, T. (1997): Climatic changes in the western part of Lake Balaton and the Great Hungarian Plain during the Quaternary: palynology, paleoclimate and paleoenvironment. - In: Ferguson, D. K. \& Kollmann, H. A. (eds): Abstracts, II. European Palaeontological Congress, Vienna, p. 57.

Járainé Komlódi, M. (1997): Veszélyes virágporok. - TermészetBÚVÁR 52: 34-35.

Fehér, Z. \& Járai-Komlódi, M. (1997): An examination of the main characteristics of the pollen season in Budapest, Hungary (1991-1996). - Grana 36: 169-174.

Járainé Komlódi, M. (1998): A legutóbbi, azaz holocén beerdősödés flóratörténetéről. (Some remarks about the Holocene flora and vegetation history in Hungary). - Bot. Közlem. 84(1-2): 3-15.

Járai-Komlódi, M. (1997): Búcsú Zólyomi Bálinttól. (In memoriam Bálint Zólyomi). Kanitzia 5: 7-13.

Járainé Komlódi, M. (1998): Nagy elődeink (Búcsú Zólyomi Bálinttól). - TermészetBÚVÁR 53: 123.

Járai-Komlódi, M. (1998): Ragweed in Hungary (Ten years' results). - Proceedings, Ragweed in Europe. 6th International Congress on Aerobiology, Satellite Symposium, Perugia, Italy, pp. 33-38.

Járainé Komlódi, M. (1998): A pollenallergiát okozó legfontosabb növények Magyarországon. - Allergológia és Klinikai Immunológia 1: 143-152.

Járainé Komlódi, M. \& Juhász, I. E. (1998): A levegő biológiai szennyezettsége parlagfü pollennel. - In: Szabó, T. \& Miriszlai, E. (szerk.): Környezeti ártalmak és a légzőrendszer. 8: $71-76$.

Nagyné Bodor, E. \& Járainé Komlódi, M. (1998): A Hévízi-tó kialakulása és története palinológiai vizsgálatokkal és a környezeti ártalmak. - In: Szabó, T. \& Miriszlai, E. (szerk.): Környezeti ártalmak és a légzőrendszer. 8: 115-125.

Borhidi, A. \& Járainé Komlódi, M. (1998): A Javorkaea (Rubiaceae) nemzetség rövid története. - Kitaibelia 3(2): 197.

Fehér, Z. \& Járai-Komlódi, M. (1998): A new weather factor predicting airborne pollen concentration: Péczely's macrosynoptic weather types. - Aerobiologia 14: 171-174.

Nagyné Bodor, E., Járainé Komlódi, M. \& Cserny, T. (1998): A Tapolcai-medence fejlődéstörténete a BTC-3. sz. fúrás palinológiai vizsgálata alapján. - Előadáskivonatok, XL. Hidrobiológus Napok, Tihany, p. 28.

Járainé Komlódi, M. (1998): Pollennaptár. - Recept nélkül (Egészségvédelmi folyóirat) 3: 16-17. 
Nagyné Bodor, E. \& Járainé Komlódi, M. (1999): Palinológiai vizsgálatok a Tapolcaimedencében. I. Vízi és mocsári növények a holocén és későglaciális időkben. Hidrológiai Közlöny 79(6): 332-333.

Járai-Komlódi, M. (1999): A magyar palinológiai kutatás atyja. - In: Glatz, F. (szerk.): Emlékbeszédek az MTA elhunyt tagjai felett 1998. Zólyomi Bálint. MTA, Budapest, pp. $11-21$.

Járainé Komlódi, M. (1999): Pollenháború. - 2. kiadás, Móra Könyvkiadó, Budapest, 132 pp.

Járainé Komlódi, M. (2000): Fekete Gábor 70 éves. Az élet és pálya fóbb állomásai. - In: Virágh, K. \& Kun, A. (szerk:). Vegetáció és dinamizmus. MTA ÖBKI, Vácrátót, pp. 9-12.

Mezei, Gy., Hank, Z., Juhász, M. \& Járai-Komlódi, M. (2000): The clinical and aeropalynological comparison of the years 1989-93 and 1994-98 in Hungary as to children with seasonal allergic rhinoconjunctivitis. - Abstracts, ACI International, Suppl. 2: 184.

Járai-Komlódi, M. (2000): Some details about ragweed airborne pollen in Hungary. Aerobiologia 16: 291-294.

Járainé Komlódi, M. (2000): Csapody Vera. - In: Bartha, D., Csapody, I. \& Szodfriedt, I. (szerk.): Mestereink. Ilyennek láttuk őket. Emlékmorzsák a közelmúlt jeles botanikusairól. Tilia 8: 28-29.

Járainé Komlódi, M. (2000): A Kárpát-medence növényzetének kialakulása. - In: Bartha, D. (szerk.): Válogatott tanulmányok II. Tilia 9: 5-59.

Nagy-Bodor, E., Járai-Komlódi, M. \& Medve, A. (2000): Late Glacial and Post-Glacial pollen records and inferred climatic changes from Lake Balaton and the Great Hungarian Plain. - In: Hart, M. B. (ed.): Climates: Past and Present. Geological Society, London, Special Publications 181: 121-133. 